\title{
Analisis Dampak Indikator Makroekonomi terhadap Investasi Portofolio di ASEAN 4
}

\author{
Adhitya Wardhono ${ }^{a}$, Ciplis Gema Qori'ah ${ }^{\mathrm{a}, \mathrm{b}}$, M. Abd. Nasir ${ }^{\mathrm{a}}$, \& Ariz Aprilia ${ }^{\mathrm{b}, *}$ \\ ${ }^{a}$ Universitas Jember \\ ${ }^{b}$ Universitas Gadjah Mada
}

\begin{abstract}
Portfolio investment is a type of investment that is vulnerable to shocks both from within and outside the country. The purpose of this study is to determine the effect of shock from inflation, interest rates and the real effective exchange rate on portfolio investments inflow in four ASEAN countries in the period 2001Q1-2018Q4. The results of the analysis using the Structural Vector Autoregressive (SVAR) method show that interest rates are the main determination of portfolio investment in Singapore and the Philippines. While inflation and the exchange rate are the main determinants of portfolio investment in Indonesia and Malaysia. This study recommends that the policy to manage capital flows in the form of portfolio investment should consider the macroeconomic variables, given the large potential risks that can be posed to economic stability, especially in the short term.
\end{abstract}

Keywords: portfolio investment; macroeconomics; SVAR; ASEAN 4

\begin{abstract}
Abstrak
Investasi portofolio merupakan jenis investasi yang rentan terhadap guncangan baik yang bersumber dari dalam maupun luar negeri. Tujuan dari studi ini adalah untuk mengetahui pengaruh guncangan variabel inflasi, suku bunga dan nilai tukar riil efektif terhadap aliran investasi portofolio di empat negara ASEAN pada periode 2001Q1-2018Q4. Hasil analisis dengan menggunakan metode Structural Vector Autoregressive (SVAR) menunjukkan bahwa suku bunga merupakan determinasi utama investasi portofolio di Singapura dan Filipina. Sedangkan inflasi dan nilai tukar menjadi determinasi utama investasi portofolio di Indonesia dan Malaysia. Studi ini merekomendasikan bahwa kebijakan pengelolaan arus modal dalam bentuk investasi portofolio sebaiknya mempertimbangkan variabel makroekonomi tersebut, mengingat besarnya potensi risiko yang dapat ditimbulkan terhadap stabilitas perekonomian terutama dalam jangka pendek.
\end{abstract}

Kata Kunci: investasi portofolio; makroekonomi; SVAR; ASEAN 4 JEL Classification: C32; G11; E10

\footnotetext{
${ }^{*}$ Alamat Penulis Korespondensi: Jln Nusantara, Bulaksumur, Yogyakarta, Indonesia, 55281. E-mail: ariz.aprilia@mail.ugm.ac.id.
} 


\section{Pendahuluan}

Aliran modal bagi semua negara terutama negara berkembang telah memberikan manfaat yang besar dalam proses pencapaian pembangunan serta pertumbuhan ekonomi dalam rangka pembiayaan investasi, memperlancar konsumsi, diversifikasi risiko, dan perluasan peluang ekonomi (Kawai \& Lamberte, 2008; Sedik dan Sun, 2012; International Monetary Fund [IMF], 2012). Hal tersebut menjadikan aliran modal sebagai fokus perhatian di kalangan para pembuat kebijakan dan juga bank sentral di masing-masing negara.

Adanya globalisasi semakin meningkatkan mobilitas arus modal asing ke negara berkembang (Rajan, 2001; Baharumshah \& Thanoon, 2006; Gu \& Huang, 2011; Davis, 2015). Bebasnya pergerakan aliran modal tersebut antara lain ditandai dengan sektor keuangan yang lebih terbuka dan cenderung memiliki hambatan pasar keuangan yang rendah (Arias et al., 2013). Meskipun sebagian negara emerging market telah mempertahankan berbagai jenis kontrol pada arus modal lintas batas (IMF, 2007), tetapi transaksi modal asing mereka ternyata jauh lebih terbuka daripada kelihatannya seperti yang umumnya ditunjukkan oleh peningkatan rasio total saham dari aset asing (Uctum \& Uctum, 2011; Bussière \& Phylaktis, 2016).

Paling tidak terdapat dua aliran modal utama yang memberi kontribusi besar terhadap jalannya perekonomian suatu negara yaitu dalam bentuk Foreign Direct Investment (FDI) dan Foreign Portfolio Investment (FPI) (Albuquerque, 2003; Schadler, 2008; Aldaba \& Yap, 2009). Kedua bentuk aliran modal tersebut memiliki masing-masing perbedaan mendasar. FDI dikaitkan dengan disertainya transfer teknologiterhadap negara penerima modal (host country). Sedangkan, FPI lebih berhubungan dengan kondisi makroekonomi dan sifat dari suatu arus modal. FPI rentan terhadap peningkatan arus modal secara tiba-tiba ("surge") dan potensi pembalikan arus modal secara cepat dalam jangka pendek ("sudden reversal") (Aldaba \& Yap, 2009; Arias et al., 2013; Wardhono et al., 2015).

Arus modal masuk dalam bentuk FPI jika tidak dikelola dengan benar maka dapat menimbulkan tiga jenis risiko bagi negara penerima modal. Ketiga jenis risiko tersebut yaitu risiko makroekonomi, risiko ketidakstabilan keuangan dan risiko pembalikan arus modal (Rodrik, 1998; Baharumshah \& Thanoon, 2006; Kawai \& Lamberte, 2008; Byrne \& Fiess, 2011). Pada titik ini masuknya FPI di satu sisi merupakan hal yang menguntungkan bagi suatu negara karena membantu dalam penyediaan modal dalam jangka pendek, tetapi di sisi lain FPI memiliki dampak negatif terkait hubungannya dengan indikator makroekonomi dan sifat dari arus tersebut (Cardarelli et al., 2010; Aizenman \& Pasricha, 2013; Ulloa et al., 2016).

Urgensi dari indikator makroekonomi dalam memengaruhi aliran modal dalam bentuk FPI telah banyak dijadikan bahan penelitian oleh beberapa peneliti. Studi Ma dan Kao (1990) menemukan bahwa indikator makroekonomi dalam bentuk apresiasi mata uang domestik berpengaruh negatif dan di lain sisi berpengaruh positif terhadap pergerakan aliran modal masuk. Sedangkan temuan 
yang agak berbeda dihasilkan dari penelitian Chuhan et al. (1993) yang menegaskan bahwa pergerakan yang berlebih pada nilai tukar mempunyai pengaruh yang berlawanan terhadap aliran modal. Indikator makroekonomi lainnya yang dijadikan penelitian yaitu suku bunga riil yang antara lain dilakukan oleh Byrne dan Fiess (2011) yang menyatakan bahwa suku bunga riil berpengaruh negatif terhadap aliran investasi portofolio yang masuk di suatu negara. Sementara hasil yang berbeda dikemukakan oleh Ekeocha et al. (2012) yang menemukan adanya hubungan positif antara suku bunga riil dan aliran masuk investasi portofolio di suatu negara.

Salah satu kawasan yang cukup menarik untuk diteliti yaitu ASEAN yang merupakan perhimpunan bangsa-bangsa di kawasan Asia Tenggara yang pada mulanya diprakarsai oleh empat (4) negara yaitu Indonesia, Malaysia, Filipina, dan Singapura (Winantyo et al., 2008; Das et al., 2013). Pada awal pembentukannya, ASEAN lebih ditujukan untuk kerja sama yang berorientasi dalam bidang politik guna mencapai kedamaian serta keamanan di kawasan Asia Tenggara, tetapi untuk semakin mensejahterakan perekonomian serta pembangunan para negara anggota ASEAN, maka dibentuk liberalisasi modal dengan salah satu tujuannya yaitu "free trade and free investment" dengan tujuan agar semakin menarik minat investor dalam menanamkan modalnya di wilayah ASEAN (Winantyo et al., 2008:78; Aldaba \& Yap, 2009).

Salah satu fakta penting terkait dengan ASEAN yaitu bahwa negara-negara anggotanya masing-masing memiliki kondisi pertumbuhan ekonomi yang tinggi dibandingkan dengan rata-rata pertumbuhan ekonomi dunia, sehingga membuat ASEAN menjadi salah satu destinasi tujuan investor untuk menanamkan modalnya (Lee et al., 2012; Kiseleva, 2012; Wardhono et al., 2014,2018). Berbagai laporan dari lembaga ekonomi dunia seperti World Bank dan IMF juga menyampaikan bahwa ASEAN menjadi kawasan yang cukup menjanjikan bagi para investor dalam rangka sebagai tempat berinvestasi modal.

Pergerakan aliran modal dalam bentuk FPI urgen dan penting untuk dicermati dan diteliti lebih lanjut karena merentang hubungan dengan risiko makroekonomi, risiko ketidakstabilan keuangan, dan risiko pembalikan arus modal. Selanjutnya, penelitian ini akan menganalisis bagaimana masing-masing indikator makroekonomi di empat Negara ASEAN ASEAN 4 yang berpengaruh terhadap aliran modal masuk dalam bentuk FPI. Indikator makroekonomi yang digunakan yaitu berupa inflasi, suku bunga, dan nilai tukar riil efektif.

\section{Tinjauan Empiris}

Banyak penelitian mengenai faktor penentu masuknya investasi portofolio baik di negara maju maupun negara berkembang. Penelitian Ahmed dan Zlate (2014) menyebutkan bahwa perbedaan tingkat suku bunga dan pertumbuhan ekonomi merupakan faktor penentu penting terhadap adanya capital inflow di suatu negara. Pada aras yang agak beda dimana dengan studi yang memperbandingkan negara emerging economies dan advanced economies, Ahmed dan Zlate (2014) me- 
nyimpulkan bahwa suatu negara dengan kecenderungan tingkat pertumbuhan ekonomi yang tinggi maka akan diiringi dengan tingkat capital inflows yang tinggi. Serta disimpulkan bahwa selama periode sebelum dan sesudah krisis telah terjadi perbedaan perilaku dari capital inflows, khususnya dalam bentuk investasi portofolio yang memiliki sensitivitas tinggi terhadap guncangan atau keadaan perekonomian global.

Lebih lanjut, berangkat dari studi Byrne dan Fiess (2011) dengan menggunakan analisis data panel menghasilkan poin temuan bahwa terdapat perbedaan perilaku aliran modal pada berbagai jenis aset keuangan di lintas negara. Selanjutnya diperoleh pula poin temuan bahwa suku bunga riil Amerika Serikat adalah faktor penentu penting dari adanya arus modal yang masuk di berbagai negara.

Kasus untuk negara emerging market dipaparkan oleh Arias et al. (2013) yang menghasilkan kesimpulan bahwa faktor penarik dan faktor pendorong merupakan faktor kunci yang berperan dalam pergerakan modal, meskipun tergantung pada jenis dari aliran modal yang masuk. Variabel yang berpengaruh signifikan terhadap adanya aliran modal adalah tingkat keterbukaan perdagangan, pertumbuhan domestik (PDB), keterbukaan keuangan ekonomi lokal, dan utang publik. Hasil penelitian juga menunjukkan bahwa adanya krisis ekonomi telah berpengaruh terhadap volume aliran modal bersih yang masuk. Krisis ekonomi telah menyebabkan perubahan dalam cara investor untuk menentukan apakah mereka harus berinvestasi atau tidak dalam pasar emerging market.

Penelitian berikutnya yaitu kajian Aizenman dan Pasricha (2013) dimana memberikan bukti empiris tentang faktor-faktor yang memotivasi negara berkembang untuk mengubah kontrol arus modal keluar dikarenakan dalam beberapa dekade terakhir terjadi liberalisasi dalam kontrol arus modal keluar. Hasil penelitian menunjukkan bahwa pendapatan represi eksternal di negara-negara emerging market menurun secara substansial di tahun 2000 dibandingkan dengan tahun 1980 dan berdampak pada pertumbuhan ekonomi serta membuat kekhawatiran terkait aliran masuk modal bersih menjadi dominan atas kebijakan fiskal dalam keputusan untuk membuat kontrol pada liberalisasi arus modal keluar. Selanjutnya, pasar negara berkembang cenderung menghadapi volatilitas yang lebih tinggi pada arus modal keluar, tekanan apresiasi yang tinggi di pasar valuta asing, serta akumulasi cadangan devisa yang lebih besar dikarenakan adanya liberalisasi pada arus modal.

Berikutnya Ekeocha et al. (2012) mengkaji tentang faktor penentu jangka panjang dari investasi portofolio asing di Nigeria mulai tahun 1981-2010. Penelitian tersebut dimaksudkan untuk memperoleh kebijakan yang tepat dalam menarik arus modal masuk dalam jangka panjang. Variabel yang dipertimbangkan dalam permodelan tersebut adalah kapitalisasi pasar, nilai tukar riil, tingkat suku bunga riil, PDB, dan tingkat keterbukaan perdagangan. Studi ini menggunakan analisis time series dan menggunakan model lag dan menghasilkan temuan bahwa investasi portofolio asing memiliki hubungan positif jangka panjang dengan kapitalisasi pasar dan tingkat keterbukaan perdagangan di Nigeria. 
Penelitian tentang faktor penentu masuknya investasi portofolio di kawasan ASEAN khususnya empat negara tersebut masih jarang dilakukan. Oleh karena itu, perspektif komprehensif untuk menyajikan bukti empiris lebih dan implikasi teoritis serta kebijakan mengenai pengaruh dari indikator makroekonomi terhadap masuknya aliran investasi portofolio di empat negara ASEAN penting untuk dilakukan.

Oleh karenanya, penelitian ini secara eksesif merujuk pada beberapa penelitian, seperti yang dilakukan oleh Ekeocha et al. (2012). Meski demikian, penelitian ini juga menaruh perhatian lebih pada indikator makroekonomi di masingmasing host country. Agarwal (1997) melakukan penelitian lebih dalam mengenai indikator makroekonomi di host country dan investasi portofolio. Merujuk hasil studi Agarwal bahwa terdapat pengaruh (negatif) antara tingkat inflasi terhadap masuknya investasi portofolio di beberapa negara berkembang. Selanjutnya, penelitian yang dilakukan oleh Waqas et al. (2015) yang menggunakan kawasan penelitian Cina, India, Pakistan, dan Sri lanka menghasilkan temuan bahwa indikator makroekonomi berupa inflasi, suku bunga, dan nilai tukar berpengaruh signifikan terhadap investasi portofolio.

\section{Metodologi}

\subsection{Data dan Variabel}

Penelitian ini menggunakan data runtun waktu dalam bentuk kuartalan dengan sampel empat NegaraASEAN pada periode 2000Q1-2018Q4. Pemillihan rentang periode tersebut dikarenakan pasca krisis ekonomi tahun 1998, sektor keuangan empat negara ASEAN lebih terbuka dan memiliki hambatan pasar keuangan yang relatif rendah terhadap pasar keuangan global (IMF, 2018a). Secara lebih rinci, berikut penjelasan definisi operasional variabel yang digunakan:

Tabel 3.1: Definisi Operasional Variabel

\begin{tabular}{llll}
\hline Notasi & Arti & Satuan & Sumber Data \\
\hline INF & Inflasi & $\%$ & International Financial Statistics \\
IR & Suku Bunga & $\%$ & International Financial Statistics \\
REER & Nilai Tukar Riil Efektif & Index & International Financial Statistics \\
FPI & Total Investasi Portofolio Asing & Miliar USD & International Financial Statistics \\
\hline
\end{tabular}

1. Inflasi (INF) merupakan kenaikan terus menerus dalam rata-rata tingkat harga yang dihitung dengan pendekatan Indeks Harga Konsumen (IHK).

2. Suku bunga (IR) merupakan suku bunga riil yang ditentukan oleh Bank Sentral masingmasing empat negara ASEAN.

3. Nilai tukar riil efektif (REER) merupakan nilait ukar nominal yang sudah dikoreksi dengan harga relatif yaitu harga-harga di dalam negeri dibandingkan dengan harga-harga di luar negeri.

4. Investasi portofolio (FPI) merupakan total investasi portofolio asing yang masuk di masingmasing empat negara ASEAN yang terdiri dari saham, obligasi, dan jenis investasi portofolio lainnya. 


\subsection{Teknik Estimasi}

Proses pengujian yang dilakukan menggunakan metode SVAR diawali dengan pembentukan restriksi yang digunakan untuk model estimasi SVAR. Restriksi dibentuk melalui teori ekonomi dan fakta empiris yang bertujuan untuk memberikan batasan dalam hubungan antarvariabel yang digunakan dalam penelitian ini. Setelah pembentukan restriksi selesai, maka selanjutnya melakukan pembentukan model SVAR yang berlandaskan pada restriksi tersebut.

Proses selanjutnya setelah pembentukan model SVAR yaitu melakukan pengujian pra estimasi. Pengujian pra estimasi ini bertujuan untuk melihat model SVAR telah memenuhi syarat untuk dianalisis. Langkah uji pra estimasi diawali dengan melakukan uji stasioneritas dengan menggunakan Augmented Dickey Fuller (ADF). Hal ini dilakukan untuk melihat stasioneritas variabel yang digunakan (Wardhono, 2004). Setelah melakukan pengujian stasioneritas dan mendapati hasil stasioner, maka proses selanjutnya yaitu melakukan uji stabilitas yang bertujuan untuk melihat kemampuan model dalam peramalan atau forecasting.

Berakhirnya pengujian pra estimasi merujuk pada langkah selanjutnya, yaitu melakukan analisispada Impulse Response Function (IRF). Pada langkah ini akan memberikan hasil atas pengaruh indikator makroekonomi terhadap pergerakan aliran investasi portofolio yang masuk dalam jangkapanjang dan jangka pendek di empat Negara kawasan ASEAN negara kawasan ASEAN 4.

Model Struktural VAR digunakan dalam penelitian ini terdiri dari empat variabel yang membentuk empat persamaan, dimana suku bunga (IR), nilai tukar riil efektif (REER), dan inflasi (INF) digunakan sebagai proksi dari indikator makroekonomi di empat negara ASEAN tersebut masing-masing negara ASEAN 4, serta total investasi portofolio sebagai proksi dari aliran modal yang diterima oleh masing-masing negara ASEAN 4. Model SVAR secara spesifik yaitu:

$$
Y_{t}=\sum_{t=0}^{\infty}\left(A_{i} U_{t-i}=A(L) U_{t}\right)
$$

dimana $U_{t}$ adalah vektor dengan empat variabel yang digunakan $\left(\operatorname{Ln}_{F P I}, \mathrm{IR}, \mathrm{RE}-\right.$ ER INF) dan $A_{i}$ merupakan countemporaneous relations antara variabel, sedangkan $\mathrm{A}(\mathrm{L})$ adalah finite-order matrix polynominal dengan operator Lag $\mathrm{L}$.

Variabel inflasi dianggap sebagai variabel independen sehingga variabel yang mendapat pengaruh adalah variabel inflasi itu sendiri. Sementara itu, variabel nilai tukar riil efektif, suku bunga, dan investasi portofolio dianggap tidak dapat mempengaruhi variabel inflasi. Dengan demikian, persamaan pertama dalam sistem SVAR adalah sebagai berikut:

$$
e_{I N F}=a_{11} \varepsilon_{I N F}
$$

Perubahan atas inflasi kemudian memengaruhi tingkat suku bunga, karena ketika ada perubahan inflasi maka variabel berikutnya yang merespons adalah suku bunga. Sehingga suku bunga dipengaruhi oleh inflasi dan perubahan pada 
suku bunga itu sendiri.

$$
e_{I R}=a_{21} \varepsilon_{I N F}+\varepsilon_{I R}
$$

Perubahan inflasi yang diikuti dengan perubahan suku bunga akan memberikan perubahan pada nilai tukar. Oleh karena itu perubahan atas inflasi nilai tukar dipengaruhi oleh inflasi, suku bunga, dan perubahan nilai tukar itu sendiri.

$$
e_{R E E R}=a_{31} \varepsilon_{I N F}+a_{32} \varepsilon_{I R}+\varepsilon_{R E E R}
$$

Investasi portofolio berikutnya diasumsikan dipengaruhi oleh inflasi, suku bunga, dan nilai tukar riil efektif dimana pada penelitian ini disebut sebagai indikator makroekonomi. Perubahan atas indikator makroekonomi kemudian memberikan perubahan terhadap investasi portofolio. Sehingga perubahan investasi portofolio dipengaruhi oleh variabel makroekonomi tersebut dan investasi portofolio itu sendiri.

$$
e_{\text {Ln-FPI }}=a_{51} \varepsilon_{I N F}+a_{52} \varepsilon_{I R}+a_{53} \varepsilon_{R E E R}+a_{54} \varepsilon_{L n_{F P I}}
$$

Penggunaan restriksi dalam penelitian ini menggunakan spesifikasi $C_{0} \varepsilon_{t}=e_{t}$ dengan $C_{0}$ diristriksi sebagai triangular matrix yang dapat menghasilkan sistem dalam just identified (Sims, 1980; Nezky, 2013). Matriks $C_{0}$ digunakan untuk mengukur structural shock pada variabel endogen sehingga dapat diartikan sebagai impact restriction. Restriksi tersebut akan membentuk persamaan residual sebagai berikut:

$$
\left[\begin{array}{c}
e_{I N F} \\
e_{I R} \\
e_{R E E R} \\
e_{\text {Ln-FPI }}
\end{array}\right]=\left[\begin{array}{cccc}
1 & 0 & 0 & 0 \\
a_{2,1} & 1 & 0 & 0 \\
a_{3,1} & a_{3,2} & 1 & 0 \\
a_{4,1} & a_{4,2} & a_{4,3} & 1
\end{array}\right]\left[\begin{array}{c}
\varepsilon_{I N F} \\
\varepsilon_{I R} \\
\varepsilon_{R E E R} \\
\varepsilon_{\text {In-FPI }}
\end{array}\right]
$$

Hasil matrik diatas kemudian dirubah ke dalam model SVAR dalam bentuk @ sebagai berikut.

$@ e 1=C(1) * @ u 1$

$@ e 2=C(2) * @ e 1+C(3) * @ u 2$

$@ e 3=C(4) * @ e 1+C(5) * @ e 2+C(6) * @ u 3$

$@ e 4=C(7) * @ e 1+C(8) * @ e 2+C(9) * @ e 3+C(10) * @ u 4$

\section{Hasil dan Pembahasan}

\subsection{Uji Stasioneritas}

Salah satu konsep penting yang harus diperhatikan dengan menggunakan data runtun waktu adalah kondisi data yang stasioner atau tidak stasioner. Apabila data stasioner, maka model runtun waktu dapat dikatakan stabil dan estimator yang dihasilkan tetap konsisten dan tidak bias (Gujarati \& Porter, 2009). Uji stasioneritas data dalam penelitian ini menggunakan unit root test. Pengujian unit 
root test dalam penelitian ini menggunakan metode ADF dengan membandingkan nilai probabilitas dengan $\alpha$ (alpha) yang digunakan. Tabel-tabel berikut ini menunjukan bahwa secara umum stasioneritas data berada pada tingkat first difference dengan signifikasi sebesar 5\%. Hasil ini menunjukkan bahwa sebelum melakukan analisis lebih lanjut, data harus diubah terlebih dahulu ke dalam bentuk first difference atau diferensi pertama.

Tabel 4.2: Hasil Uji Akar Unit Indonesia

\begin{tabular}{lcccc}
\hline Indonesia & Prob. LN $F P I$ & Prob. IR & Prob. REER & Prob. INF \\
\hline Level & 0,2190 & $0,0000^{*}$ & 0,9377 & 0,2008 \\
$1^{\text {st }}$ Difference & $0,0075^{*}$ & $0,0000^{*}$ & $0,0000^{*}$ & $0,0000^{*}$ \\
$2^{\text {nd }}$ Difference & $0,0000^{*}$ & $0,0000^{*}$ & $0.0000^{*}$ & $0,0000^{*}$ \\
\hline
\end{tabular}

Sumber: Bank Indonesia (2018) (diolah)

Keterangan: * signifikan $\alpha=5 \%$

Tabel 4.3: Hasil Uji Akar Unit Malaysia

\begin{tabular}{lcccc}
\hline Malaysia & Prob. LN $F P I$ & Prob. IR & Prob. REER & Prob. INF \\
\hline Level & $0,0026^{*}$ & 0,0903 & 0,5014 & 0,3901 \\
$1^{\text {st }}$ Difference & $0,0148^{*}$ & $0,0001^{*}$ & $0,4518^{*}$ & $0,0066^{*}$ \\
$2^{\text {nd }}$ Difference & $0,0000^{*}$ & $0,0000^{*}$ & $0,0000^{*}$ & $0,0000^{*}$ \\
\hline
\end{tabular}

Sumber: International Financial Statistics (IFS) (IMF, 2018b) (diolah)

Keterangan: * signifikan $\alpha=5 \%$

Tabel 4.4: Hasil Uji Akar Unit Singapura

\begin{tabular}{lcccc}
\hline Singapura & Prob. LN $F P I$ & Prob. IR & Prob. REER & Prob. INF \\
\hline Level & 0,2740 & 0,1086 & 0,1009 & 0,2722 \\
$1^{\text {st }}$ Difference & $0,0384^{*}$ & $0,0007^{*}$ & $0,0075^{*}$ & $0,0000^{*}$ \\
$2^{\text {nd }}$ Difference & $0,0000^{*}$ & $0,0000^{*}$ & $0,0000^{*}$ & $0,0000^{*}$ \\
\hline Sumber: IFS (2018) (diolah) & & &
\end{tabular}

Sumber: IFS (2018) (diolah)

Keterangan: * signifikan $\alpha=5 \%$

Tabel 4.5: Hasil Uji Akar Unit Filipina

\begin{tabular}{lcccc}
\hline Filipina & Prob. LN $F P I$ & Prob. IR & Prob. REER & Prob. INF \\
\hline Level & $0,0081^{*}$ & 0,1540 & 0,6840 & 0,5792 \\
$1^{\text {st }}$ Difference & $0,0000^{*}$ & $0,0000^{*}$ & $0,0002^{*}$ & $0,0046^{*}$ \\
$2^{\text {nd }}$ Difference & $0,0001^{*}$ & $0,0000^{*}$ & $0,0000^{*}$ & $0,0000^{*}$ \\
\hline
\end{tabular}

Sumber: IFS (2018) (diolah)

Keterangan: * signifikan $\alpha=5 \%$

\subsection{Pemilihan Lag Optimum}

Pengujian lag optimum pada penelitian ini bertujuan untuk menemukan panjang lag terbaik untuk model VAR (Wardhono et al., 2019b). Panjang lag memberikan 
pengaruh terhadap estimasi VAR dan berpengaruh dalam menghindarkan model untuk terbebas dari masalah autokorelasi dan heterokedastisitas. Berdasarkan hasil pengujian Tabel 4.5, Indonesia perlu menggunakan Lag 4, sedangkan untuk tiga negara lainnya menggunakan lag 5 .

Tabel 4.6: Hasil Uji Lag Optimum di ASEAN 4

\begin{tabular}{lcccccc}
\hline Negara & Lag & LR & FPE & AIC & SC & HQ \\
\hline Indonesia & 4 & $56,24^{*}$ & $2,67^{*}$ & $58,34^{*}$ & $60,54^{*}$ & $59,21^{*}$ \\
Malaysia & 5 & $38,91^{*}$ & $33,74^{*}$ & $19,39^{*}$ & $22,11^{*}$ & $20,47^{*}$ \\
Singapura & 5 & $49,28^{*}$ & $71,48^{*}$ & $17,84^{*}$ & $20,56^{*}$ & $18,92^{*}$ \\
Filipina & 5 & $28,22^{*}$ & $72,36^{*}$ & $20,15^{*}$ & $22,87^{*}$ & $21,79^{*}$ \\
Sumber: Bank Indonesia (2018) dan IFS (2018) (diolah) \\
Keterangan: * menunjukkan masing-masing lag optimum
\end{tabular}

\subsection{Uji Stabilitas Model}

Pengujian stabilitas model merupakan pengujian penting dalam melihat stabilitas model SVAR yang akan digunakan (Wardhono et al., 2019c). Penggunaan uji stabilitas yaitu untuk mendapatkan model SVAR yang stabil untuk dianalisis pada Impulse Response Function (IRF) dan Variance Decomposition (VD). Syarat stabilitas model SVAR yang dibentuk adalah nilai dari modulus kurang dari 1 atau berada pada unit circle (Gujarati \& Porter, 2009). Dari Gambar 4.1 berikut dapat diketahui bahwa sebaran titik inverse root of $A R$ pada masing-masing negara berada di dalam lingkaran. Hasil ini menunjukkan bahwa model penelitian ini dikatakan stabil dan dapat dilanjutkan untuk estimasi tahap selanjutnya.

\subsection{Hasil Estimasi}

Hasil analisis menggunakan model SVAR dapat dijabarkan melalui analisis Impulse Response Function (IRF). Analisis ini didasarkan pada nilai-nilai koefisien IRF yangmenjelaskan informasi tentang respons salah satu variabel endogen terhadap perubahan sebesar satu standar deviasi pada seluruh variabel endogen. Dengan menggunakan analisis IRF, berikut beberapa hasil analisis respons variabel indikator makroekonomi terhadap investasi portofolio di empat Negara ASEAN masing-masing negara ASEAN 4.

Gambar 4.2 menunjukkan respons dari investasi portofolio terhadap beberapa indikator makroekonomi yaitu suku bunga, inflasi, dan nilai tukar selama periode pengamatan. Guncangan yang pertama yaitu terjadi pada suku bunga direspons positif oleh investasi portofolio pada awal periode sampai periode ke-3. Sementara pada periode ke-4 sampai ke-8 direspons positif. Kondisi pada investasi portofolio yang merespons positif pada awal periode sampai pada periode ke-3 diakibatkan oleh terjadinya perubahan ketetapan besaran tingkat suku bunga yang digunakan dalam pasar valuta asing. Selanjutnya mulai peiode ke-40 menunjukkan fluktuasi yang mulai mengecil yang menandakan bahwa investasi portofolio kembali mencapai keseimbangan. 


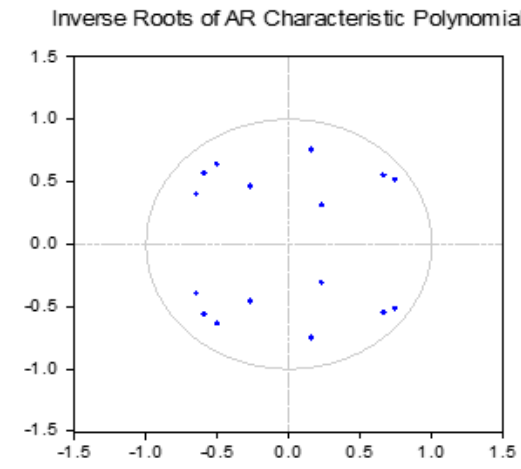

Inverse Roots of AR Charac teristic Polynomial

\section{Indonesia}

Inverse Roots of AR Characteristic Polynomial

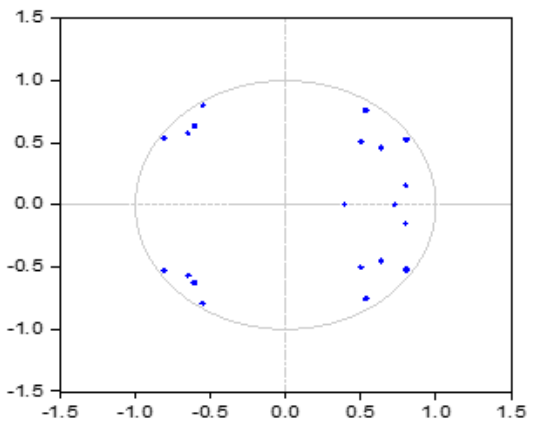

Malaysia

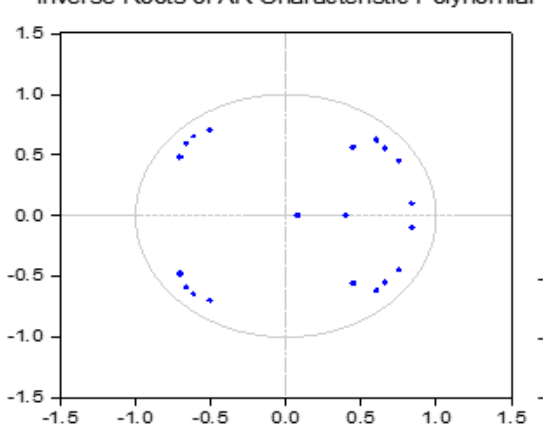

Filipina

Inverse Roots of AR Characteristic Polynomial

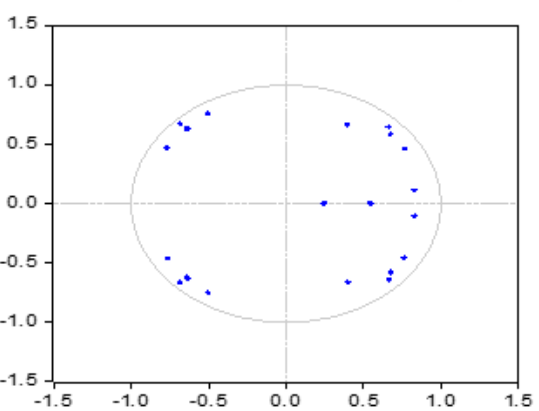

Thailand

Gambar 4.1: Uji Stabilitas Model di Masing-Masing Negara ASEAN 4 Sumber: Bank Indonesia (2018) dan IFS (2018) (diolah)
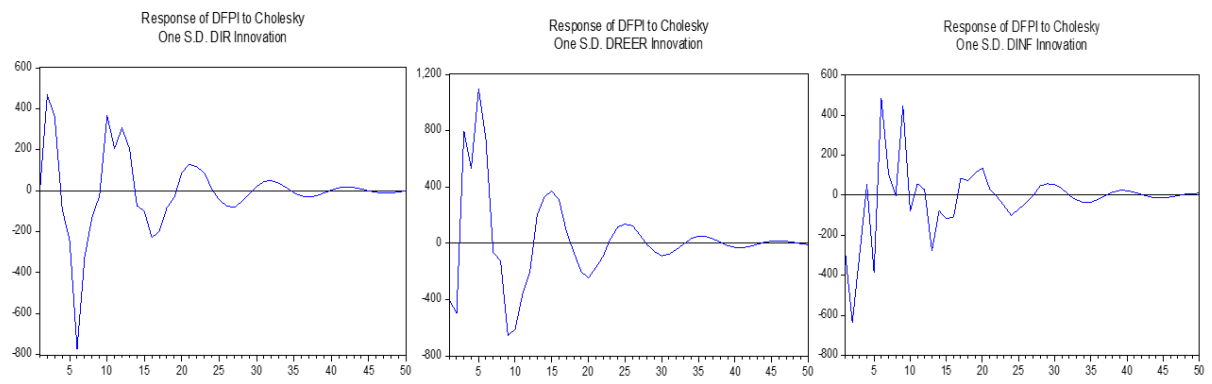

Gambar 4.2: IRF di Indonesia

Sumber: Bank Indonesia (2018) (diolah) 
Selanjutnya yaitu guncangan yang disebabkan oleh nilai tukar. Terlihat guncangan yang direspons negatif pada periode ke-1 sampai ke-5. Berikutnya pada periode ke-6 hingga ke-12, direspons positif. Kondisi terjadinya guncangan pada nilai tukardapat diakibatkan oleh penetapan kebijakan bank sentral dalam mengatur jumlah uang beredar (Wardhono, 2019a). Setelah itu terjadi pergerakan yang sedikit berfluktuatif dan pada awal periode ke-40 investasi portofolio sudah kembali menuju keseimbangan semula.

Pengujian IRF selanjutnya yaitu guncangan yang disebabkan oleh inflasi yang direspons negatif oleh investasi portofolio pada awal periode. Selanjutnya inflasi direspons negatif pada periode ke-1 sampai ke-2. Pada periode ke-3 hingga ke-7, investasi portofolio merespons negatif. Respons investasi portofolio yang berfluktuatif di Indonesia antara lain diakibatkan oleh terjadinya peningkatan harga barang yang menyebabkan peningkatan inflasi. Kemudian keadaan inflasi yang bergejolak memengaruhi keputusan investor dalam menanamkan modalnya.
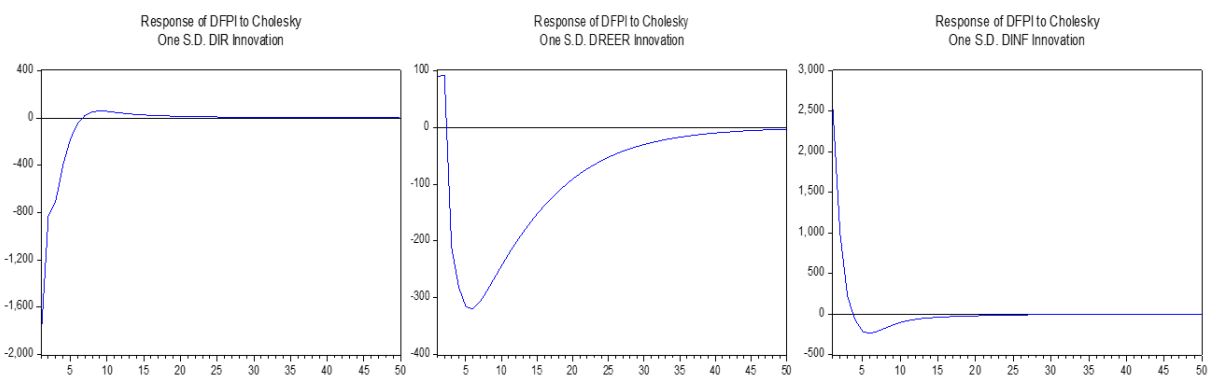

Gambar 4.3: IRF di Malaysia

Sumber: IFS (2018) (diolah)

Guncangan pertama yaitu berasal dari suku bunga. Guncangan tersebut direspons negatif oleh investasi portofolio pada awal periode hingga periode ke- 8 . Setelah itu mulai periode ke-9, guncangan mulai mengecil. Respons yang sama juga ditunjukkan oleh nilai tukar. Pada periode ke-1 dan ke-2, guncangan yang disebabkan oleh nilai tukar direspons positif oleh investasi portofolio, setelah itu mulai periode ke-3 hingga ke-42 terjadi respons negatif. Investasi portofolio selanjutnya menuju keseimbangan semulapada periode ke 43. Berikutnya, investasi portofolio merespons secara positif atas guncangan yang disebabkan oleh inflasi pada periode ke-1 hingga ke-4, setelah itu direspons negatif hingga periode ke- 19 . Pada awal periode ke-20, investasi portofolio sudah tidak merespons guncangan atas inflasi tersebut.

Investasi portofolio di Singapura cenderung merespons negatif atas guncangan yang terjadi pada tingkat suku bunga pada periode ke-1 sampai ke- 4 . Setelah itu terjadi respons yang berfluktuatif baik positif maupun negatif. Dari hasil analisis IRF tersebut, maka dapat diartikan bahwa berubahnya besaran suku bunga begitu berpengaruh terhadap aliran investasi portofolio yang masuk 

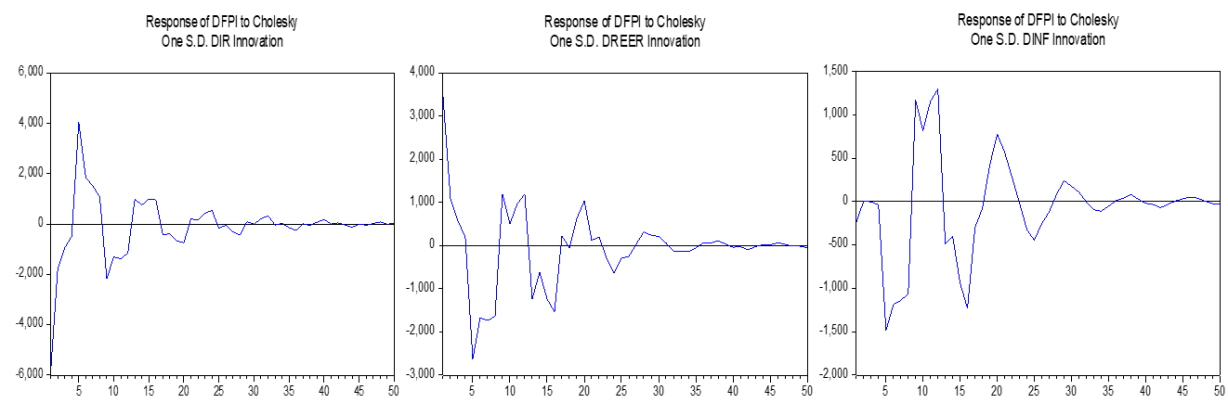

\section{Gambar 4.4: IRF di Singapura}

Sumber: IFS (2018) (diolah)

di Singapura. Berikutnya, dari Gambar 4.4 dapat diketahui bahwa guncangan yang terjadi pada investasi portofolio atas nilai tukar dan inflasi juga sangat berfluktuatif sama seperti guncangan yang disebabkan oleh suku bunga. Hal ini mengimplikasikan bahwa suku bunga, inflasi, dan nilai tukar merupakan indikator makroekonomi penting yang menjadi perhatian para investor dalam menanamkan investasinya di Singapura.
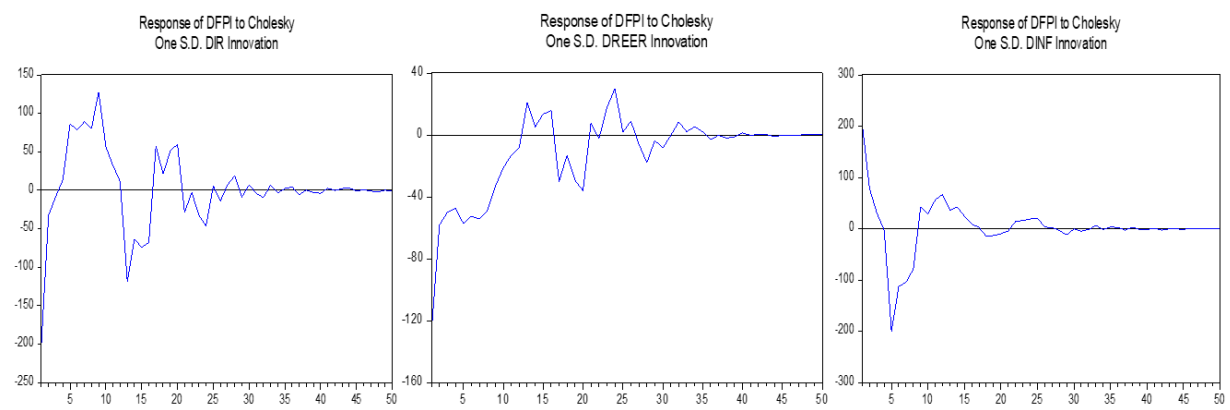

Gambar 4.5: IRF di Filipina

Sumber: IFS (2018) (diolah)

Investasi portofolio merespons negatif atas guncangan suku bunga pada periode ke-1 hingga ke-3, setelah itu mulai periode ke-4 hingga ke-11 merespons positif. Berikutnya terjadi respons positif maupun negatif. Investasi portofolio kembali menuju keseimbangan pada awal periode ke-45. Kondisi ini menandakan bahwa suku bunga di Filipina memberikan pengaruh yang cukup besar terhadap investasi portofolio. Respons positif selanjutnya yaitu terlihat pada guncangan yang disebabkan oleh nilai tukar dimana sama berfluktuatifnya dengan guncangan yang disebabkan oleh suku bunga. Terakhir, terjadi guncangan positif yang disebabkan oleh inflasi pada periode ke-1 hingga ke-3, setelah itu 
terjadi guncangan dengan kecenderungan negatif dan tidak berfluktuatif, serta terlihat menuju keseimbangan semula pada periode ke-42.

\section{Pembahasan dan Kesimpulan}

Suku bunga merupakan salah satu indikator makroekonomi yang menjadi acuan investor dalam berinvestasi. Dari hasil IRF diketahui bahwa suku bunga merupakan indikator utama yang memengaruhi investasi portofolio di Singapura dan Filipina. Hasil ini antara lain sesuai dengan penelitian yang dilakukan oleh Ahmed dan Zlate (2014) yang menyatakan bahwa suku bunga memiliki pengaruh yang besar terhadap besar kecilnya investasi portofolio. Hal tersebut dikarenakan bahwa Singapura sebagai negara high income di ASEAN dan Singapura juga merupakan negara dengan pendapatan per kapita tertinggi ketiga di dunia. BUMN memainkan peran besar dalam perekonomian dengan memegang saham mayoritas di beberapa perusahaan terbesar di Singapura, seperti Singapore Airlines, SingTel, STEngineering, dan Media Corp. Investor juga sangat tertarik untuk berinvestasi di Singapura karena iklim investasi yang sangat menarik dan suhu politik yang stabil (Asian Development Bank [ADB], 2012). Sementara itu, Filipina juga merupakan salah satu negara di ASEAN yang memiliki iklim investasi yang menarik. Prospek bisnis di negara ini cukup baik karena berbagai aturan regulasi telah diperbaiki oleh pemerintah dalam rangka menarik aliran investasi masuk. Salah satunya yaitu bank sentral Filipina telah menggunakan suku bunga sebagai salah satu transmisi yang penarik investor asing untuk menanamkan modalnya.

Berikutnya, guncangan yang disebabkan oleh nilai tukar dan inflasi ternyata paling berpengaruh terhadap investasi portofolio yang masuk ke Indonesia. Hal tersebut antara lain dikarenakan Indonesia merupakan salah satu destinasi favorit setelah Singapura untuk investor dalam menginvestasikan dananya. Oleh karena itu, Indonesia perlu menjaga fluktuasi nilai tukar agar investasi portofolio yang masuk dapat dikelola dengan baik. Selain itu, besar kecilnya inflasi harus dapat dikendalikan oleh otoritas moneter agar kestabilan perekonomian dapat senantiasa terjaga. Terakhir yaitu guncangan nilai tukar menjadi indikator makroekonomi utama yang mempengaruhi investasi portofolio yang masuk ke Malaysia. Dari hasil tersebut, maka pemerintah Malaysia perlu lebih berhati-hati dalam mengelola pergerakan nilai tukarnya.

Atas dasar rangkaian hasil analisis yang telah diuraikan, kami menyarankan bahwa kebijakan pengelolaan arus modal dalam bentuk investasi portofolio yang mempertimbangkan masing-masing indikator makroekonomi diperlukan bagi empat negara ASEAN. Kebijakan ini penting mengingat potensi guncangan yang dapat ditimbulkan dari masing-masing indikator makroekonomi. Fenomena aliran modal masuk yang cepat (surge) dan pembalikan modal yang cepat (sudden reversal) yang dialami oleh berbagai negara advanced economies maupun emerging market alangkah baiknya menjadi perhatian utama pengambil kebijakan agar investasi portofolio dapat dimanfaatkan dan dikelola dengan optimal. 


\section{Daftar Pustaka}

[1] ADB. (2012). Annual Report 2012: Advancing regional cooperation and integration in Asia and the Pacific. Asian Development Bank. https://www.adb.org/sites/default/files/ institutional-document/33806/adb-annual-report-2012.pdf.

[2] Agarwal, R. N. (1997). Foreign portfolio investment in some developing countries: A study of determinants and macroeconomic impact. Indian Economic Review, 32(2), 217-229.

[3] Ahmed, S., \& Zlate, A. (2014). Capital flows to emerging market economies: A brave new world?. Journal of International Money and Finance, 48(Part B), 221-248. doi: https://doi.org/10.1016/j.jimonfin.2014.05.015.

[4] Aizenman, J., \& Pasricha, G. K. (2013). Why do emerging markets liberalize capital outflow controls? Fiscal versus net capital flow concerns. Bank of Canada Working Paper 2013-21. https:/ / www.bankofcanada.ca/2013/07/working-paper-2013-21/.

[5] Albuquerque, R. (2003). The composition of international capital flows: risk sharing through foreign direct investment. Journal of International Economics, 61(2), 353-383. doi: https: / / doi.org/10.1016/S0022-1996(03)00013-8.

[6] Aldaba, R. M., \& Yap, J. T. (2009). Investment and capital flows: Implications of the ASEAN economic community. Discussion Paper Series 2009-01. Philippine Institute for Development Studies. https://dirp3.pids.gov.ph/ris/dps/pidsdps0901.pdf.

[7] Arias, F., Garrido, D., Parra, D., \& Rincon, H. (2013). Do the different types of capital flows respond to the same fundamentals and in the same degree? Recent evidence for emerging markets. 4th BIS Consultative Council for the Americas conference "Financial stability, macroprudential policy and exchange rates", Santiago, Chile, 25-26 April 2013. https://www.bis.org/events/ccaconf2013/ariasetal.pdf.

[8] Baharumshah, A. Z., \& Thanoon, M. A. M. (2006). Foreign capital flows and economic growth in East Asian countries. China Economic Review, 17(1), 70-83. doi: https://doi.org/10.1016/j.chieco.2005.09.001.

[9] Bank Indonesia. (2018). Laporan perekonomian Indonesia tahun 2018. https:/ /www.bi. go.id/id/lip/infografis/Pages/BI-Infografis-LPI-2018.aspx.

[10] Bussière, M., \& Phylaktis, K. (2016). Emerging markets finance: Issues of international capital flows-Overview of the special issue. Journal of International Money and Finance, 60, 1-7. doi: https://doi.org/10.1016/j.jimonfin.2015.09.007.

[11] Byrne, J. P., \& Fiess, N. (2011). International capital flows to emerging and developing countries: National and global determinants. SIRE Discussion Papers 2011-03. Scottish Institute for Research in Economics (SIRE). https://ideas.repec.org/p/edn/sirdps / 245.html.

[12] Cardarelli, R., Elekdag, S., \& Kose, M. A. (2010). Capital inflows: Macroeconomic implications and policy responses. Economic Systems, 34(4), 333-356. doi: https://doi.org/10.1016/j.ecosys.2010.01.004.

[13] Chuhan, P., Claessens, S., \& Mamingi, N. (1993). Equity and bond flows to Asia and Latin America: The role of global and country factors. Policy, Research Working Papers WPS 1160. Debt and International Finance. Washington, DC: World Bank. http://documents.worldbank.org/curated/en/551091468753025200/ Equity-and-bond-flows-to-Asia-and-Latin-America-the-role-of-global-and-countryfactors.

[14] Das, S. B., Menon, J., Severino, R. C., \& Shrestha, O. L. (Eds.). (2013). The ASEAN economic community: A work in progress. Institute of Southeast Asian Studies. 
[15] Davis, J. S. (2015). The cyclicality of (bilateral) capital inflows and outflows. Globalization and Monetary Policy Institute Working Paper, 247. Federal Reserve Bank of Dallas. https://www.dallasfed.org/-/media/documents/institute/wpapers/2015/ 0247.pdf.

[16] Ekeocha, P. C., Ekeocha, C. S., Malaolu, V., \& Oduh, M. O. (2012). Modelling the long run determinants of foreign portfolio investment in Nigeria. Journal of Economics and Sustainable Development, 3(8), 194-205.

[17] Gu, X., \& Huang, B. (2011). A new approach to capital flows: Theory and evidence. Economic Modelling, 28(3), 1050-1057. doi: https://doi.org/10.1016/j.econmod.2010.11.023.

[18] Gujarati, D. N., \& Porter, C. D. (2009). Basic econometrics (5th Edition). McGraw-Hill Irwin.

[19] IMF. (2007). International Monetary Fund Annual Report 2007: Making the global economy work for all. International Monetary Fund. https://www.imf.org/en/Publications/AREB/Issues/2016/12/31/

Annual-Report-of-the-Executive-Board-for-the-Financial-Year-Ended-April-30-2007.

[20] IMF. (2012). International Monetary Fund Annual Report 2012: Working together to support global recovery. International Monetary Fund. https:/ / www.imf.org/en/Publications/AREB/Issues/2016/12/31/

International-Monetary-Fund-Annual-Report-2012-Working-Together-To-SupportGlobal-Recovery-26104.

[21] IMF. (2018a). IMF Annual Report 2018: Building a shared future. International Monetary Fund. https://www.imf.org/external/pubs/ft/ar/2018/eng/assets/pdf/ imf-annual-report-2018.pdf.

[22] IMF. (2018b). International Financial Statistic Monthly 10/2018. International Monetary Fund. https://www.elibrary.imf.org/doc/IMF041/25151-9781484354179/ 25151-9781484354179/Other_formats/Source_PDF/25151-9781484354223.pdf? redirect=true.

[23] Kawai, M., \& Lamberte, M. (2008). Managing capital flows in Asia: Policy issues and challenges. ADBI Research Policy Brief, 26. Asian Development Bank Institute. https://www.adb.org/publications/ managing-capital-flows-asia-policy-issues-and-challenges.

[24] Kiseleva, A. (2012). Cross-border investments under Asean+3's monetary and financial cooperation. International Conference on Management, Economics and Finance, 15t-16 October 2012, Sarawak, Malaysia.

[25] Lee, H. H., Huh, H. S., \& Kim, W. J. (2012). Cross-border portfolio investment in the APEC region. Japan and the World Economy, 24(1), 44-56. doi: https://doi.org/10.1016/j.japwor.2011.11.002.

[26] Ma, C. K., \& Kao, G. W. (1990). On exchange rate changes and stock price reactions. Journal of Business Finance \& Accounting, 17(3), 441-449. doi: https://doi.org/10.1111/j.1468-5957.1990.tb01196.x.

[27] Nezky, M. (2013). The impact of US crisis on trade and stock market in Indonesia. Bulletin of Monetary, Economics and Banking, 15(3), 83-96. doi: https://doi.org/10.21098/bemp.v15i3.428.

[28] Rajan, R. (2001). Economic globalization and Asia: Trade, finance and taxation. CIES Discussion Paper, 0150. Center for International Economic Studies, Adelaide University.

[29] Rodrik D (1998) Who needs capital-account convertibility? In S. Fischer, R. N. Cooper, 
R. Dornbusch, P. M. Garber, C. Massad, J. J. Polak, D. Rodrik, \& S. S. Tarapore (Eds.), Should the IMF pursue capital account convertibility? (Essays in international finance No. 207) (pp. 55-65). Princeton: Department of Economics, Princeton University.

[30] Sarno, L., Tsiakas, I., \& Ulloa, B. (2016). What drives international portfolio flows?. Journal of International Money and Finance, 60, 53-72. doi: https://doi.org/10.1016/j.jimonfin.2015.03.006.

[31] Schadler, S. (2010). Managing large capital inflows: Taking stock of international experiences. ADB Institute Discussion Paper, 97. Asian Development Bank Institute. https://www.adb.org/publications/ managing-large-capital-inflows-taking-stock-international-experiences.

[32] Sedik, T. S., \& Sun, T. (2012). Effects of capital flow liberalizationWhat is the evidence from recent experiences of emerging market economies? IMF Working Paper WP/12/275. International Monetary Fund. https://www.imf.org/en/Publications/WP/Issues/2016/12/31/ Effects-of-Capital-Flow-Liberalization-What-is-the-Evidence-from-RecentExperiences-of- 40108 .

[33] Sims, C. A. (1980). Macroeconomics and reality. Econometrica, 48(1), 1-48. doi: $10.2307 / 1912017$.

[34] Uctum, M., \& Uctum, R. (2011). Crises, portfolio flows, and foreign direct investment: An application to Turkey. Economic Systems, 35(4), 462-480. doi: https://doi.org/10.1016/j.ecosys.2010.10.005.

[35] Waqas, Y., Hashmi, S. H., \& Nazir, M. I. (2015). Macroeconomic factors and foreign portfolio investment volatility: A case of South Asian countries. Future Business Journal, 1(1-2), 65-74. doi: https://doi.org/10.1016/j.fbj.2015.11.002.

[36] Wardhono, A. (2004). Mengenal ekonometrika: Teori dan aplikasi (Edisi Pertama). Fakultas Ekonomi Universitas Jember.

[37] Wardhono, A., Salim, A., \& Qoriah, C. G. (2014). The effects of European bilateral debt crisis on international banking finance behavior in the Philippines and Indonesia. International Journal of Economic Perspectives, 8(3), 41-51.

[38] Wardhono, A., Arisandi, D., \& Nasir, M. A. (2018). Empirical study of scapegoat theory paradigm in the exchange rate variable in the ASEAN 5. International Economic Journal, 32(1), 102-119. doi: https:/ / doi.org/10.1080/10168737.2018.1446998.

[39] Wardhono, A., Nasir, M. A., Qori'ah, C. G., \& Sarwedi. (2015). Movement Effects of Portofolio Investment Againts Real Effective Exchange Rate Stability in ASEAN. In H. Paramu \& Sudaryanto (Eds.), International Conference Proceedings: Business Management: Directions and Strategies in Response to ASEAN Economic Community 2015 (pp. 41-58), Jember, 2 November 2013. Faculty of Economics and Business, University of Jember.

[40] Wardhono, A., Indrawati, Y., Qoriah, C. G., \& Nasir, M. A. (2019a). Perilaku kebijakan bank sentral di Indonesia. Pustaka Abadi.

[41] Wardhono, A., Indrawati, Y., Qoriah, C. G., \& Nasir, M. A. (2019b). Analisis data time series dalam model makroekonomi. Pustaka Abadi.

[42] Wardhono, A., Indrawati, Y., Qori'ah, C. G., \& Nasir, M. A. (2019c). Structural cointegrating vector auto regression approach in macroeconomic model. The 5th SBE International Conference on Business and Economy 2019, March 13-14, Universitas Katolik Soegijapranata, Semarang, Indonesia.

[43] Winantyo, R., Saputra, R. D., Fitriani, S., Morena, R., Kosotali, A., Saichu, G., Rohmadyati, U., Sholihah, Rachmanto, A., \& Gandara, D. (2008). Masyarakat Ekonomi 
ASEAN (MEA) 2015: Memperkuat sinergi ASEAN di tengah kompetisi global. Elex Media Komputindo. 